\title{
Vírusellenes terápiás lehetőségek COVID-19 fertőzés kezelésére
}

\author{
Keserű György Miklós \\ Gyógyszerkémiai Kutatócsoport, Természettudományi Kutatóközpont, Budapest, Magyarország \\ Magyar Koronavírus-kutatási Akciócsoport \\ Beérkezett: 2021. április 23.; Elfogadva: 2021. május 11.
}

\begin{abstract}
Összefoglalás
A COVID-19-járvány egyre növekvő számú fertőzött betegének ellátása érdekében rövid időn belül szükség mutatkozott vírusellenes terápiás lehetőségekre. A gyors reagálás szempontját figyelembe véve erre a célra elsősorban más vírusok ellen már kifejlesztett vírusellenes szerek jöhetnek szóba. A magyar betegek ellátásbiztonsága szempontjából különösen fontos a hatóanyagok és gyógyszerkészítmények hazai gyártása. Ezt a cél tűzte ki a favipiravir, egy széles spektrumú antivirális hatóanyag hazai fejlesztése, amely sikeresen befejeződött, a gyógyszerkészítmény klinikai vizsgálata folyamatban van.
\end{abstract}

Kulcsszavak: vírusellenes szerek, favipiravir, remdesivir, fejlesztés, gyártás, klinikai vizsgálatok

\section{Antiviral therapies for COVID-19 infections}

\author{
György M. Keserú \\ Medicinal Chemistry Research Group, Research Centre for Natural Sciences, Budapest, Hungary \\ Hungarian Coronavirus Research Task Force \\ keseru.gyorgy@ttk.hu
}

\begin{abstract}
Summary
Increasing impact of COVID-19 on the healthcare system prompted the identification of potential antiviral therapies. Due to the immediate demand, known drugs were subjected to repositioning attempts. These drugs include agents inhibiting the viral entry into the host cells, drugs potentially blocking the release of the viral RNA from the endosomes, antivirals inhibiting the replication of the viral RNA and finally compounds that might prevent the assembly of the new virion. Since there is less experience with camostat and nafamostat, the entry inhibitors tested in Japan, and due to the ambiguous data collected with the endosome blocking chloroquine and hydroxyl-chloroquine, we focused on the actual antiviral treatment options for COVID-19 infections. In addition to favipiravir and remdesivir that were used early, at the onset of the pandemic, we discuss novel candidates including molnupiravir, a promising antiviral actually investigated in clinical trials. Considering the needs of Hungarian COVID patients and the security of supply as first priority, we selected favipiravir and developed a convenient process for the industry-scale production of the active pharmaceutical ingredient (API). At the end of this review we summarize the development and clinical investigation of favipiravir, a wide spectrum antiviral drug used for the treatment of mild and moderate COVID patients in Hungary in both ambulant and clinical settings. The Hungarian COVID Task Force set up two consortia, one for the development and the other for the clinical investigations of favipiravir. The objective of the favipiravir development consortium was to develop processes for the production of Favipiravir API and dosage forms. The consortium completed the pilot plant scale industrial production of the API and produced clinical samples for the upcoming trials. The selection and laboratory scale optimization of the synthesis route was performed at the Medicinal Chemistry Research Group of the Research Center for Natural Sciences. The laboratory scale synthesis was scaled up for pilot plant production at EVI plc and Gedeon Richter plc. GMP production was realized at the facilities of Gedeon Richter plc. Finished dosage forms were developed at Meditop Ltd who produced the clinical samples under GMP conditions. The clinical consortium is headed by the Hungarian section of the European Clinical Research Infrastructure Network (ECRIN) and organized two trials. One of these trials investigates favipiravir produced in Hungary while the other trial is performed with favipiravir produced in Japan. Both studies were approved by the Hungarian regulatory agency (OGYÉI) and are ongoing.
\end{abstract}

Keywords: antivirals, favipiravir, remdesivir, pharmaceutical development, pharmaceutical production, clinical investigations 
A 2020 elejére világméretû járvánnyá vált COVID-19 fertőzés egészségügyi, gazdasági és társadalmi szempontból egyaránt új helyzet elé állította még a legfejlettebb országokat is. A tudomány és a kutatók együttmúködése meghatározó szerepet játszott a COVID-19 betegség szakaszainak, az ezeket jellemző alapvető kórtani folyamatoknak, valamint magának a kórokozónak a megismerésében. A lehetséges terápiák kidolgozásához pedig pontosan ezekből az ismeretekből lehet kiindulni. Ha egy betegség lehetséges terápiáit keressük, elsőként át kell tekintenünk a betegség lefolyását és szakaszait.

A betegség a megfertőződéssel kezdődik, majd egy rövid, néhány napos inkubációs szakaszt követóen jelentkeznek az első tünetek: többek között láz, köhögés, fáradtság, fejfájás (He et al. 2020). Ezek jelzik, hogy megkezdődött a betegség úgynevezett virális szakasza, mely körülbelül hét-nyolc napig tart. Ezután a fertőzöttek egy részénél nehézlégzés alakul ki, melynek hátterében legtöbbször kezdődő tüdőgyulladás áll. A tüdőgyulladás már a gyulladásos szakasz kezdetét jelzi, majd a tünetek súlyosbodásával a gyulladás kiterjed a teljes tüdőre, sőt akár más szervekre is. A fellépő légzési nehézségek miatt ezek a betegek már nyilvánvalóan kórházi ellátásra szorulnak. A gyulladásos folyamatok kiterjedésével szükség lehet légzéstámogatásra, intenzív terápiás ellátásra. A gyulladás előrehaladtával a gyulladásos faktorok gyors és lökésszerú fellépése vezethet a citokinvihar kialakulásához, amely életveszélyes állapotot is okozhat (Tobaiqy et al. 2020).

A fertőzés kezdeti szakaszában az emberi szervezetet jelentôs vírusterhelés éri. A COVID-19 betegséget okozó SARS-Cov-2-vírus ( $i$-De Clercq 2020), amelyről a járvány kezdetén viszonylag keveset tudtunk, az úgynevezett koronavírusok családjába tartozik, mely az elnevezését onnan kapta, hogy a felszínén tüskeszerú kinövéseket okozó fehérjék azonosíthatók. A vírusfertőzés során a vírus tüskefehérjéje egy, az emberi sejt felszínén lévő másik fehérjéhez, az ACE2-höz kapcsolódik (Lan et al. 2020), így a vírus és az emberi sejt kapcsolatba kerülnek. Ekkor egy, a sejt membránjában kifejeződő fehérje, a TMPRSS2 proteáz (Hoffmann et al. 2020) elvágja ezt a tüskefehérjét, és ezzel elindul az a folyamat, melynek során a vírus bekerül a sejt belsejébe. A sejt belsejébe került vírusból ezt követően kiszabadul a virális RNS. Az RNSfüggő RNS-polimeráz fehérje segítségével megkezdődik a virális RNS szaporítása, a replikáció. A felszaporított virális RNS ezt követően transzláció hatására virális fehérjévé alakul, amelyből egy proteáz-enzim segítségével létrejönnek a vírus fehérjéi. Végül ezek a fehérjék összeépülnek, és a kész vírus elhagyja a sejtet (1.ábra).

A vírus szaporodásában szerepet játszó fehérjék megismerése a lehetséges terápiák kidolgozása szempontjából is kulcsfontosságú, hiszen ezek jelentik azokat a beavatkozási lehetőségeket, ahol a gyógyszeres terápiának helyet kereshetünk. Így például megakadályozhatjuk, hogy a vírus a tüskefehérje segítségével az emberi sejt felszínén lévő receptorhoz kapcsolódjon. Vagy meggá-

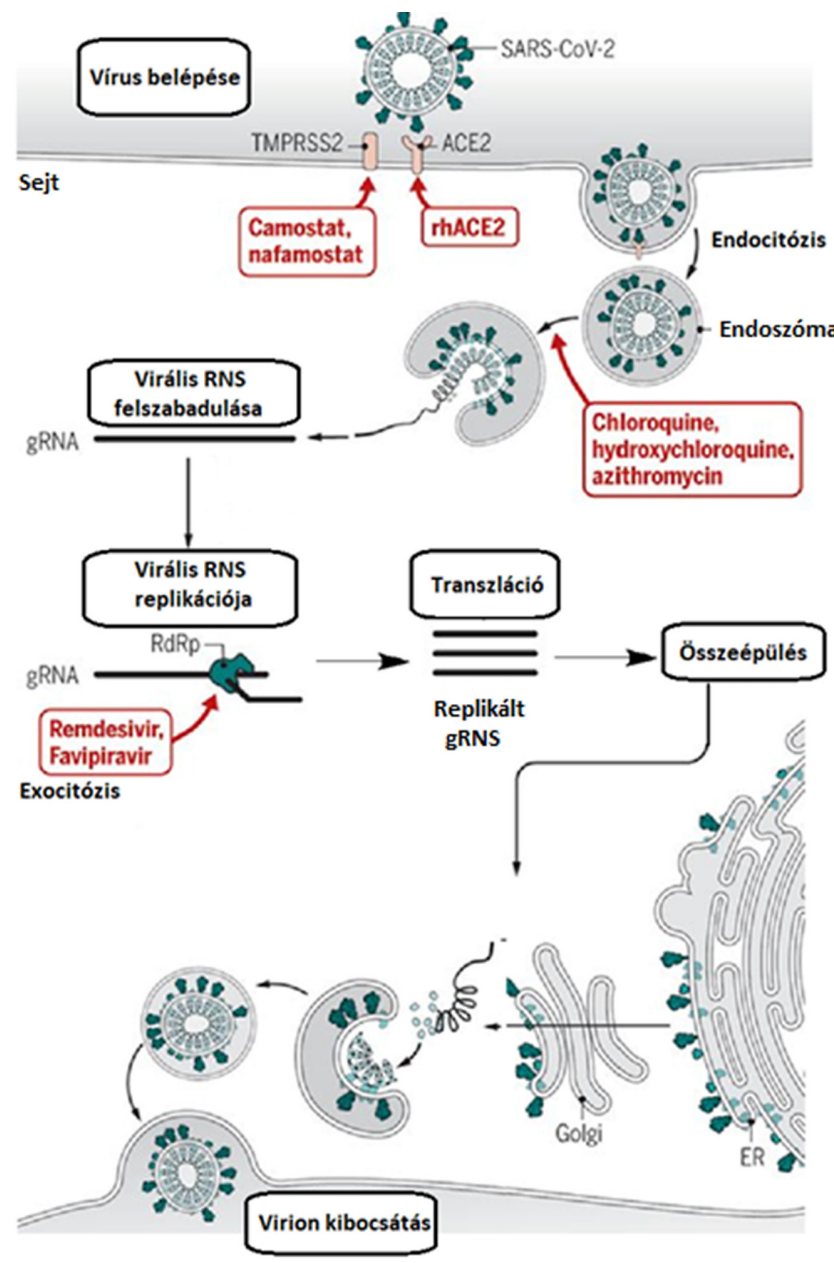

1. ábra Újrapozicionálási lehetőségek a SARS-Cov-2 koronavírus életciklusában (Guy et al. 2020 alapján)

tolhatjuk például, hogy a sejt membránjában található proteáz elvágja a tüskefehérjét, és ezáltal megkezdődjön a vírus bejutása a sejtbe. Lehetőségünk van azonban arra is, hogy magának a virális RNS-nek a replikációját vagy transzlációját gátoljuk, és ezáltal megakadályozzuk a vírus szaporodását.

Mit tehet a tudomány akkor, amikor az emberiség egy addig ismeretlen vírussal, egy korábban ismeretlen betegséggel találkozik? Hogyan segítheti a gyógyszerkutatás és fejlesztés a küzdelmet, amely a vírus szaporodásának megállításáért, a járvány felszámolásáért indul?

Nyilvánvaló, hogy a legjobb megoldás egy új gyógyszer kifejlesztése lenne, melyet akár a fertózöttek kezelésére vagy a fertőzés megelőzésére is fel tudunk használni. Sajnos egy új gyógyszer kifejlesztése hosszú folyamat: számtalan gyógyszerjelölt molekula részletes vizsgálata, fehérje-kölcsönhatások tesztelése, sejtes modellek, állatmodellek alkalmazása jellemzi az úgynevezett preklinikai gyógyszerkutatási szakaszt, amely alapesetben több évet vesz igénybe. A gondosan optimált molekula hatékonyságát és biztonságosságát ezt követően klinikai vizsgálatokban szükséges igazolni. A folyamatot végül, mintegy 
8-10 évvel a kutatások megkezdését követően, a gyógyszer hatósági engedélyezése zárja.

A fertőzöttek számának gyors emelkedése, a járvány terjedése azonban nem ad ennyi időt a lehetséges terápiák azonosítására. A koronavírus okozta fertőzések kezelésére a lehető legrövidebb időn belül kell megoldást találnunk. Nyilvánvaló megoldás lehet egy új vakcina kifejlesztése: ez a folyamat gyakorlatilag már a koronavírus-járvány kitörésekor, jelentős erőforrások bevonásával, párhuzamosan indult el a világ több kutatólaboratóriumában és gyógyszergyárában. Azonban egy vakcina fejlesztése és engedélyezése alapesetben nem sokkal rövidebb, mint egy új gyógyszeré. Ezért bármennyire is türelmetlenül várjuk már a járványhelyzet megszúnéséhez szükséges nagy mennyiségú vakcinát, az alig egy évnyi fejlesztési időt lehetővé tevő rendkívüli erőfeszítést és széles körû́ nemzetközi összefogást mindenképpen értékelni kell. Ráadásul, az oltási kampányok logisztikai nehézségei, az oltási hajlandóság alakulása és az újonnan megjelenó vírusváltozatok miatt a vakcinák mellett is szükség van hatékony antivirális terápiás lehetőségekre.

Mit tehetünk tehát addig, amíg a vakcinafejlesztések és az oltási kampányok révbe érnek, amikor a fertőzöttek száma folyamatosan növekszik, és az egészségügyi ellátórendszerek a múködőképességük határára kerülnek? Ilyenkor az egyik legjobb megoldás a meglévő gyógyszerkincs felhasználása. Ekkor olyan gyógyszereket keresünk, amelyeket már valamilyen más betegségben sikeresen alkalmaztak, és esélyes, hogy az indikációjuk kiterjesztésével, vagy esetleg indikáción kívüli alkalmazással koronavírusos betegek kezelésére is alkalmasak lehetnek.

A vírus gazdaszervezetbe történő bejutását a TMPRSS2 fehérjét gátló szerin proteáz inhibitorok segítségével kísérelték meg gátolni, amelyek közül a camostatot (Hoffmann et al. 2020), illetve a nafamostatot (Wang et al. 2020) érdemes megemlíteni. A camostat 1985-ben Japánban került törzskönyvezésre, eredetileg hasnyálmirigy-gyulladás indikációban. Alkalmazása szerinproteáz-gátló hatásának köszönhetően merült fel COVID-19 fertőzöttek kezelésére. Hasonló hatásmechanizmussal rendelkezik a nafamostat, amelyet 1999- ben, szintén Japánban törzskönyveztek. Jóllehet mindkét gyógyszer sikeresen gátolta a vírus szaporodását humán in vitro kísérletekben, az alacsony betegszámú és jellemzően nem klinikai vizsgálatban történt alkalmazás alapján jelenleg nem lehet egyértelmú következtetést levonni a hatékonyságukra. A gyógyszerek hatékonyságának és biztonságosságának igazolására további vizsgálatok szükségesek.

A vírusfertőzés kialakulását az ACE2 fehérje és a vírus tüskefehérjéje közötti felismerés gátlásával is meg lehet akadályozni. Erre a megközelítésre példa a ma már hazánkban is elérhető bamlavinimab, az első ideiglenes engedéllyel rendelkező monoklonális antitest terápia, amelyet az első amerikai gyógyult betegek egyikéból vett vérmintából fejlesztettek ki. A bamlavinimab (Gottlieb et al. 2021) a SARS-CoV-2 koronavírus semlegesítésére alkalmas, rekombináns technológiával előállított $\operatorname{IgGl} \kappa$ típusú monoklonális antitest, amely a vírus tüskefehérjéjének receptorkötő alegységéhez kapcsolódik, és ezáltal megakadályozza, hogy a tüskefehérje az emberi sejtek felszínén jelen lévő ACE2 receptorokhoz kapcsolódjon.

A virális RNS endoszómából történő kijutása gátlásában tulajdonítottak szerepet a klorokinnak, illetve a hidroxiklorokinnak (Wang et al. 2020). A klorokin egy 1934-ben Németországban felfedezett maláriaellenes gyógyszer, amelyet profilaxisban is használnak, míg hidroxiklorokint 1955-ben az Egyesült Államokban regisztrálták autoimmun gyulladások, illetve reumatoid artritisz kezelésére. E vegyületek esetében azonban többféle hatásmechanizmus is felmerült: elképzelhetőnek tartották például, hogy a virális RNS kijutásának gátlása az endo-/ lizoszóma $\mathrm{pH}$-változtatásával történik, vagy a közvetlen RNS-kötődés miatt gátolt a transzláció, vagy általánosabban, a vírusfertőzés következményeképpen kialakuló gyulladásra hatva fejtik ki hatásukat. Bár a korai in vitro és in vivo vizsgálatok reményt keltőek voltak, a klinikai vizsgálatok e gyógyszerek hatékonyságát COVID-19 fertőzésben nem igazolták. A klorokin és a hidroxiklorokin esete ezért jó példa arra, hogy az újrapozicionálás sikerességét egyedül tudományos igényú klinikai vizsgálatokban lehet bizonyítani.

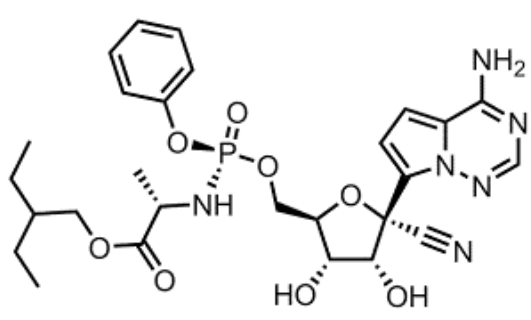

remdesivir<smiles>NC(=O)c1nc(F)cnc1O</smiles>

favipiravir

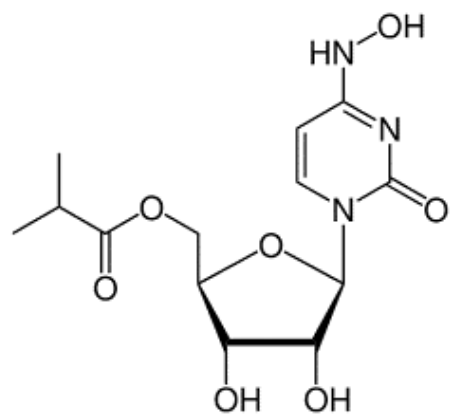

molnupiravir 
Az RNS-vírusok ellen ható antivirális szerek egyik legfontosabb támadáspontja az RNS-függő RNS polimeráz, amelyre korábban több specifikus gátlószert is kifejlesztettek (Hoffmann et al. 2020). Tekintettel arra, hogy a COVID-19 fertőzést okozó SARS-CoV-2-vírus is az RNS vírusok családjába tartozik, a COVID-19 járvány kezdetén leginkább ezeket a gyógyszereket kísérelték meg alkalmazni. A COVID-19 fertőzések magyarországi megjelenésekor az Operatív Törzs döntése alapján a Természettudományi Kutatóközpont által vezetett konzorcium partnereivel egy ilyen terápiás megoldás lehetőségét kívánta biztosítani a magyar lakosság számára. Választásunk a betegség kezdeti, virális szakaszában alkalmazható vírusellenes terápiákra esett, ugyanis két vírusellenes készítmény, a remdesivir és a favipiravir (2. ábra) hatékonyságát előzetes klinikai vizsgálatokban már megerősítették (Martinez 2020).

Mindkét hatóanyag a vírus szaporodásáért közvetlenül felelős enzim, az RNS-függő RNS-polimeráz gátlásával fejti ki hatását. A remdesivir eredeti indikációja hepatitis C, ebola, illetve Marburg-vírusfertőzés volt (JorgensenKebriaei-Dresser 2020). Bár ezekben a betegségekben a remdesivir nem volt hatékony, alkalmazhatóságát COVID-19 fertőzésben több, tudományos igényességgel végzett klinikai vizsgálat is megerősítette. A remdesivir használata ugyanakkor kórházi ellátáshoz kötött, intravénás adagolást igényel, ezért többnyire nem a fertőzés kezdeti szakaszában, inkább a középsúlyos, súlyos betegek terápiájában kerül alkalmazásra.

Egy másik, szintén vírusellenes vegyület a favipiravir, amit 2014-ben, Japánban engedélyeztek eredetileg influenza A és B fertőzések kezelésére. A favipiravir egy széles spektrumú antivirális szer, így az influenza mellett az ebola, a nyugat-nílusi láz, különböző koronavírustípusok ellen is hatékonynak bizonyult (Furuta-KomenoNakamura 2017). 2020 októberében ért véget az első tudományos igényű klinikai vizsgálat Japánban, amely megerôsítette, hogy a favipiravir az enyhe és középsúlyos tüneteket mutató koronavírusos betegeken hatékonynak bizonyult (https://www.fujifilm.com/jp/en/ news/hq/5451). A favipiravir nagy előnye, hogy szájon át adagolható, így az alkalmazása nem feltétlenül kötött kórházi ellátáshoz: több országban már kórházi ellátáson kívül is elérhető.

E közlemény írásakor a favipiravirral kapcsolatban 35 klinikai vizsgálat folyik a világ 24 országában (https:// clinicaltrials.gov/ct $2 /$ results? recrs=\&cond=Covid $19 \& t$ erm=favipiravir). Az első, korai vizsgálatok vészhelyzeti forgatókönyv alapján indultak, tudományos igényü bizonyítást nem tettek lehetővé, azonban reményt keltettek azzal kapcsolatban, hogy a favipiravir alkalmas lehet koronavírus-fertőzöttek kezelésére. Ezt követően a japán, a második kínai, az orosz, illetve a 2020 októberében publikált japán vizsgálat volt az, amelyik megerósítette a favipiravir hatékonyságát. Jelenleg az Egyesült Államokban, Ázsia több országában, az Egyesült Királyságban, Olaszországban, és erőfeszítéseinknek köszönhetően
Magyarországon is folynak klinikai vizsgálatok favipiravir készítményekkel COVID-19 fertőzésben.

Célkitűzésünknek megfelelően három projektet indítottunk el az Innovációs és Technológiai Minisztérium támogatásával. Az első projekt a favipiravir hatóanyag gyártására szolgáló eljárás fejlesztése és egy, betegek kezelésére alkalmas klinikai készítmény előállítása volt. Ezt a projektet és a laboratóriumi eljárás fejlesztését a Természettudományi Kutatóközpont vezette, a nagyobb léptékú előállításhoz szükséges méretnövelést az Első Vegyi Industria Zrt. végezte, végül a félüzemi eljárás kidolgozása a Richter Gedeon Nyrt. feladata volt. Az előállított hatóanyagból a klinikai vizsgálatra kerülő gyógyszerkészítményt a Meditop Gyógyszeripari Kft. állította elő. A további két projekt a favipiravir hazai klinikai vizsgálatát tûzte ki célul, amelyhez a magyar gyógyszert és a japán referenciakészítményt használjuk. A klinikai vizsgálatok szervezésében a HECRIN konzorciumra, lebonyolításában az Adware Research Kft.-re támaszkodtunk. A vizsgálatokban részt vesznek az orvostudományi egyetemek klinikai centrumai, így a pécsi, szegedi, debreceni klinikai centrum, a Semmelweis Egyetem, valamint két kiemelt COVID-ellátóhely, a Dél-pesti Centrumkórház Országos Hematológiai és Infektológiai Intézet, valamint az Országos Korányi Pulmonológiai Intézet.

Egy gyógyszerhatóanyag elóállítására alkalmas eljárás kidolgozását a laboratóriumban kell kezdeni. Ezt követi a méretnövelés első lépése, ami már nagyobb léptékben és így nagyobb mennyiségben teszi lehetővé a hatóanyag előállítását. Az emberi felhasználásra kerülő klinikai mintát pedig szigorúan ellenőrzött körülmények között, kiterjedt minőség-ellenőrzés és minőségbiztosítás mellett, úgynevezett félüzemi körülmények között állítjuk elő. A sikeres klinikai vizsgálatokat követően a gyártás már üzemi körülmények között történik.

A favipiravir-fejlesztés annak ellenére, hogy egy viszonylag egyszerú molekuláról van szó, rendkívül sok kihívással jár. Egyrészt azért, mert a hatóanyag előállítására számos lehetőség kínálkozik (Titova-Fedorova 2020), és viszonylag rövid idő alatt kell megtalálnunk ezek közül a legjobbat. Másrészt a COVID-19 járvány jelentette korlátozások miatt az alap- és segédanyagok beszerzése komoly logisztikai kihívást jelent. Ráadásul a minőség-ellenőrzéshez párhuzamosan kell fejleszteni a szükséges analitikai módszereket, amelyek nélkülözhetetlenek a gyártás köztitermékei, illetve a végtermék gyógyszerhatóanyag tisztaságának és megfelelőségének megállapításában. A járvány első hullámának felfutása a rendelkezésre álló erőforrások maximális kihasználását követelte. Áprilisban jutottunk el a Magyarországon laboratóriumban előállított első favipiravir-tételhez. Májusban már a méretnövelés volt soron, amikor a laboratóriumi eszközökből az EVI Zrt. laboratóriumában már félkilós méretben gyártottunk, majd alig egy hónappal később a Richter Nyrt. félüzemében már többkilós tételben tudtunk hatóanyagot gyártani (3. ábra). 


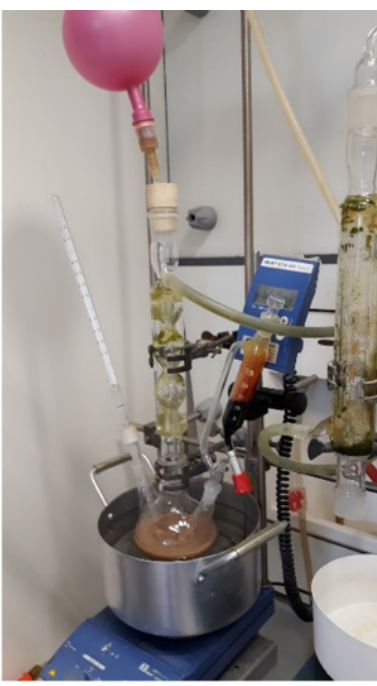

TTK: $10 \mathrm{~g}(2020.04 .06$.

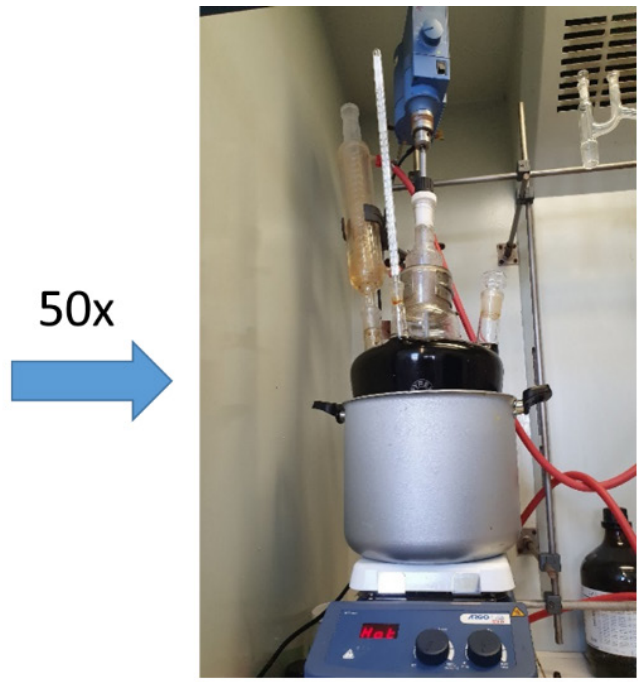

EVI ZRt: 500 g (2020. 05. 04.)

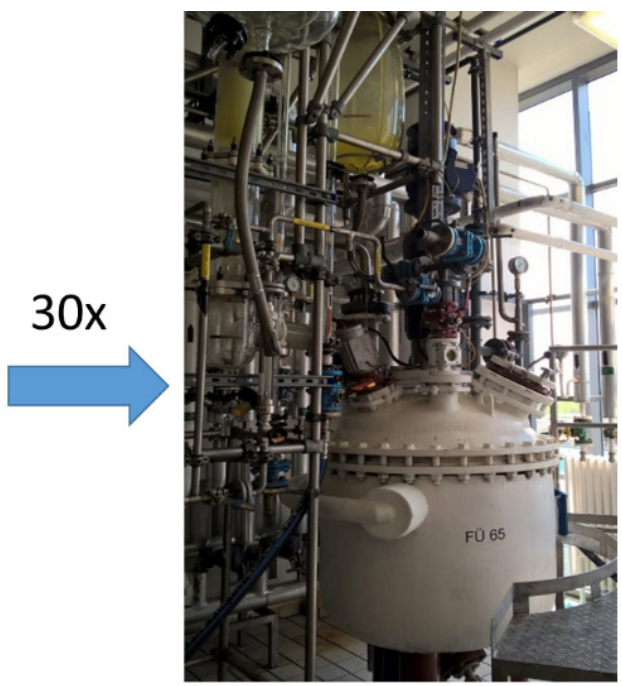

Richter NyRt: 15 kg (2020. 06. 08.)

3. ábra | A favipiravir elóállítására alkalmas eljárás egy lépésének méretnövelése

Az elkészült favipiravir-hatóanyagból a betegek kezelésére alkalmas gyógyszerkészítményt a Meditop Gyógyszeripari Kft. állította elő. A gyógyszerkészítmény hatékonyságát és biztonságosságát jelenleg klinikai vizsgálatokban tanulmányozzuk.

A gyógyszerfejlesztés és engedélyezés hatósági szabályainak megfelelően egy gyógyszernek több klinikai fejlesztési fázison kell sikeresen átjutnia ahhoz, hogy a szükséges hatósági engedélyeket megszerezve terápiás alkalmazásra kerüljön. A fázis 1 vizsgálatok során egészséges önkénteseken a biztonságosságot, az adagolást és a farmakokinetikai paramétereket vizsgálják. A fázis 2 vizsgálatok során, általában 100-300 betegen a biztonságosság és a hatékonyság kérdése kerül előtérbe, amit végül nagyobb elemszámon végzett fázis 3 vizsgálatban kell megerősíteni. A favipiravir készítményekkel a Pécsi Tudományegyetem vezette konzorcium két klinikai vizsgálatot folytat, egyrészt a Külgazdasági és Külügyminisztérium jóvoltából Japánból érkezett japán favipiravir-tartalmú gyógyszerkészítménnyel egy fázis 3 vizsgálatot, valamint a magyar favipiravir készítménnyel egy fázis 2 vizsgálatot. Mindkét vizsgálat célja a favipiravir hatékonyságának és biztonságosságának igazolása COVID-19 fertőzésben. Ezek a klinikai vizsgálatok a magyar kórházakban folynak, ott, ahol a járvány felfutásával szinte emberfeletti munka folyt. Ezért különösen nagy tisztelet és megbecsülés jár azoknak az orvosoknak, akik ezek között a körülmények között is vállalkoznak arra, hogy klinikai vizsgálatban alkalmazzák akár a japán, akár a magyar gyógyszerkészítményt.

Addig is, amíg ezek a vizsgálatok befejeződnek, a favipiravir-tartalmú gyógyszerkészítmények Magyarországon indikáción kívüli alkalmazás formájában elérhetőek. Az Országos Gyógyszerészeti és Élelmezés-egészségügyi Intézet engedélye alapján a favipiravirt jelenleg is folyamatosan használják koronavírusos betegeknek a kezelé- sére, ez a kezelési lehetőség szerepel a Magyar Koronavírus Kézikönyvben. A kedvező tapasztalatok alapján a favipiravir hatékonynak és biztonságosnak bizonyult a koronavírus-fertőzés kezdeti, virális szakaszában. A kezdeti tapasztalatok azt mutatták, hogy a favipiravir a fertőzést követő 7-10 napban alkalmazható a legnagyobb sikerrel. Ezért Kovács L. Gábor és Makara B. Gábor akadémikusokkal közösen javaslatot tettünk a gyógyszer alapellátásban történő alkalmazására, amellyel nemcsak a tünetek enyhítése érhető el, hanem az ellátórendszer terhelése is csökkenthető lehet. Javaslatunk alapján a járvány harmadik hullámának elindulásakor, 2021. március elején az Emberi Erőforrások Minisztériuma engedélyezte a favipiravir alapellátásban történő alkalmazását, így a gyógyszert már a háziorvosok is rendelhetik.

Az újrapozicionált remdesivir és a favipiravir mellett új RNS-függő RNS polimeráz gátlószerek fejlesztése is megkezdődött, amelyek közül a molnupiravir (2. ábra) van legközelebb az engedélyezéshez (Painter et al. 2021). Hasonlóan a remdesivirhez, a molnupiravir is prodrugként múködő nukleozid-analóg, azonban adagolása szájon át történik. A gyógyszer fejlesztését az Emory Egyetemen eredetileg influenza indikációban kezdték, azonban az emberi koronavírusok szélesebb csoportjában is hatékonyságot mutatott. Az egyetem egy biotechnológiai vállalkozáson keresztül biztosított jogokat a fejlesztést jelenleg is végző gyógyszervállalatnak, ennek köszönhetően a molnupiravirt már fázis 2 és 3 klinikai vizsgálatokban tesztelik mind kórházban, mind pedig otthonukban gyógyuló betegeken. Az első eredmények 2021 első félévében várhatóak.

A COVID-19 járvány váratlanul érte a világot - az eddigi tanulságok egyértelműen megmutatták, hogy a felkészültség alapvető fontosságú. Meg kellett szervezni a védőeszköz-ellátást, a lakosság tájékoztatását, és meg kellett erősíteni az egyéni védekezés tudatosságát. Az 
egészségügyi ellátórendszert fel kellett készíteni a nagyszámú fertőzött ellátására. Az elmúlt közel egy évben, a kutatások és fejlesztések eredményeképpen új terápiás lehetôségek és protokollok jöttek létre, illetve a vakcinák megjelenésével esélyt kaptunk a megelőzésre, a járvány megfékezésére. Jóllehet 2021 elejétől növekvő számú vakcina kap forgalomba hozatali engedélyt, azonban a járvány megállításához szükséges átoltottság elérése sajnos nem megy egyik napról a másikra. A vakcinagyártás és -disztribúció jelentős logisztikai kihívásai, valamint az oltási kampányok megszervezésének és lebonyolításának nehézségei miatt valószínúsíthetjük, hogy a vírus nem tûnik el nyomtalanul.

Feltehetően még hosszabb ideig szükség lesz olyan gyógyszeres terápiákra, és a gyógyszeres terápiák lehetőségét nyújtó stratégiai készletekre, amelyek a koronavírus-fertózöttek számára megteremtik az ellátásbiztonságot. A vírusellenes gyógyszerek magyarországi gyártásának megszervezésével és a megvalósított fejlesztésekkel a hazai gyógyszerfejlesztéssel foglalkozó szakemberek példaértékú összefogása ezt a célt szolgálja.

\section{Köszönetnyilvánítás}

Köszönettel tartozunk mindazoknak a kollégáknak, akik a magyar favipiravir hatóanyag és gyógyszerkészítmény fejlesztésében és klinikai vizsgálatában részt vettek.

\section{Irodalomjegyzék}

Furuta, Y., Komeno, T., \& Nakamura, T. (2017) Favipiravir (T-705), a broad spectrum inhibitor of viral RNA polymerase. Proceedings of the Japan Academy. Series B, Physical and biological Sciences,
Vol. 93. No. 7. pp. 449-463. https://doi.org/10.2183/ pjab.93.027

Gottlieb, R. L. et al. (2021) Effect of Bamlanivimab as Monotherapy or in Combination With Etesevimab on Viral Load in Patients With Mild to Moderate COVID-19: A Randomized Clinical Trial. JAMA, Vol. 325. No. 7. pp. 632-644.

Guy, R. K. et al. (2020) Rapid repurposing of drugs for COVID-19. Science (New York, N.Y.) Vol. 368. No. 6493. pp. 829-830.

He, X. et al. (2021) Clinical Symptom Differences Between Mild and Severe COVID-19 Patients in China: A Meta-Analysis. Frontiers in Public Health, Vol. 8. 561264.

Hoffmann, M. et al. (2020) SARS-CoV-2 Cell Entry Depends on ACE2 and TMPRSS2 and Is Blocked by a Clinically Proven Protease Inhibitor. Cell, Vol. 181. No. 2. pp. 271-280.e8.

Jorgensen, S., Kebriaei, R., \& Dresser, L. D. (2020) Remdesivir: Review of Pharmacology, Pre-clinical Data, and Emerging Clinical Experience for COVID-19. Pharmacotherapy, Vol. 40. No. 7. pp. 659-671.

Lan, J. et al. (2020) Structure of the SARS-CoV-2 spike receptorbinding domain bound to the ACE2 receptor. Nature, Vol. 581. No. 7807. pp. 215-220.

Li, G., \& De Clercq, E. (2020) Therapeutic options for the 2019 novel coronavirus (2019-nCoV). Nature reviews. Drug Discovery, Vol. 19. No. 3. pp. 149-150.

Martinez, M. A. (2020) Clinical Trials of Repurposed Antivirals for SARS-CoV-2. Antimicrobial Agents and Chemotherapy, Vol. 64. No. 9. e01101-20.

Painter, W. P. et al. (2021) Human Safety, Tolerability, and Pharmacokinetics of Molnupiravir, a Novel Broad-Spectrum Oral Antiviral Agent with Activity Against SARS-CoV-2. Antimicrobial Agents and Chemotherapy, AAC.02428-20.

Titova, Y. A. \& Fedorova, O. V. (2020) Favipiravir - a Modern Antiviral Drug: Synthesis and Modifications. Chemistry of Heterocyclic Compounds, Vol. 56. pp. 659-662.

Tobaiqy, M. et al. (2020) Therapeutic management of patients with COVID-19: a systematic review. Infection Prevention in Practice, Vol. 2. No. 3. 100061.

Wang, M. et al. (2020). Remdesivir and chloroquine effectively inhibit the recently emerged novel coronavirus $(2019-\mathrm{nCoV})$ in vitro. Cell Research, Vol. 30. No. 3. pp. 269-271. 